\title{
A Participatory Approach to Minimizing Food Waste in the Food Industry-A Manual for Managers
}

\author{
Christina Strotmann ${ }^{1, *}$, Christine Göbel ${ }^{1}$, Silke Friedrich ${ }^{1}$, Judith Kreyenschmidt ${ }^{2}$, \\ Guido Ritter ${ }^{1}$ and Petra Teitscheid ${ }^{1}$ \\ 1 Institute of Sustainable Nutrition (iSuN), Münster University of Applied Sciences, Corrensstr. 25, \\ 48149 Münster, Germany; Christine.Goebel@fh-muenster.de (C.G.); Silke.Friedrich@fh-muenster.de (S.F.); \\ gritter@fh-muenster.de (G.R.); teitscheid@fh-muenster.de (P.T.) \\ 2 Institute of Nutritional and Food Sciences, Cold Chain Management Working Group, University of Bonn, \\ Katzenburgweg 7-9, 53115 Bonn, Germany; j.kreyenschmidt@uni-bonn.de \\ * Correspondence: Christina.Strotmann@fh-muenster.de; Tel.: +49-251-8365572
}

Academic Editors: Riccardo Accorsi and Riccardo Manzini

Received: 10 November 2016; Accepted: 30 December 2016; Published: 5 January 2017

\begin{abstract}
Based on their experiences gained in 15 companies in the catering sector and the bakery industry, the authors present a participatory concept to reduce food waste in the food industry. This five-phase concept, adapted to the PDCA (Plan-Do-Check-Act) cycle applied in the Total Quality Management, involves a participatory approach where employees are integrated into the process of developing and implementing measures to counteract food waste. The authors describe how the participatory approach can be used to raise awareness of the topic of food waste to improve employee commitment and responsibility. As a result, the authors further offer a Manual for Managers wishing to reduce food waste in their respective organizations. This manual includes information on the methodologies applied in each step of the improvement cycle. It also describes why the steps are necessary, and how results can be documented. The participatory concept and the Manual for Managers contribute to reducing food waste and to enhancing resource efficiency in the food industry.
\end{abstract}

Keywords: food waste; change management; resource efficiency; sustainability; food value chain; PDCA cycle

\section{Introduction}

In Germany, 18 million tons of food are wasted annually on its way from the farm to the end consumer [1]. Before entering the retail or consumer level, the food produced has undergone various process steps along the food value chain, starting with agricultural production. During these processes, resources such as energy, water, and other materials are necessary for the conversion of the raw material to the end product. Therefore, wasting food also includes discarding all the other resources which have been used during production and transport. In times of scarce resources, the efficient use of land, energy, water, and other assets is crucial. Moreover, politicians and customers have called on the food industry to accept social responsibility for its impact on customers, society, and the environment [2].

Previous research has focused on determining food waste and the underlying reasons for it, either from the producer or consumer perspective [3-8]. Several tools and concepts have been introduced, which enable managers to analyze the status quo in their institutions and which present measures to combat food waste. Examples include the Food Loss E Waste Protocol (FLW Protocol), a multi-stakeholder partnership, which has developed the global FLW Standard [9]; WRAP's (Waste and Resources Action Programme) pack entitled Taking Action on Waste; the Business Case for Hospitality and Food [10]; Zero Waste Scotland's guide, Measuring to Manage Resources and Wastes: An introduction [11]; the Supply Chain Walk Problem Solving Tool by the IGD Institute of Grocery Distribution ) [12]; a Checklist 
introduced by United against Waste [13]; the Checklist for manufacturers and retailers issued by "genießt uns", a German governmental initiative [14]; the Food Waste Audit guide from FoodSave [15]; and the Manual for caterers and suppliers-Reducing food waste together developed by the Institute of Sustainable Nutrition (iSuN) [16]. These tools represent only a small sample of the more than 500 concepts and tools that are available in German and English [17]. Nevertheless, recent studies have also revealed a need to integrate employees into the approaches applied. For example, in a study conducted in a Welsh hospital by Sonnino and McWilliam [18], the authors discovered the need for a more integrated approach that takes into account all groups along the food value chain to counteract food waste. Until now, concepts have focused on waste reduction at the various stages of the supply chain by conducting problem analysis. Such an approach, however, fails to offer a holistic concept that integrates employees, customers, and other relevant stakeholders into the process of problem analysis, and the development or implementation of measures to counteract food waste. Such a comprehensive concept must be applied in order to benefit from employees' knowledge and experience, to gain a better understanding of customers' motivations and attitudes, and to enhance their commitment to the task of food waste reduction. Such a participatory concept, which is both solution-oriented and stakeholder-oriented, not only provides information on how to analyze the status quo and general measures to apply, but also enables managers to identify organization-specific problem areas and develop solution-oriented measures by integrating the relevant stakeholder groups involved in the processes along the food value chain.

\section{Aims and Objectives}

This article aims to present a participatory concept that can be used to reduce the quantity of food wasted in the food sector. The authors describe a five-phase concept with participatory elements, which was originally developed for three projects conducted in bakeries and the food service sector. The concept can also be applied in any other food company belonging to the crafts sector, as well as industry, retail, or large-scale consumers. Special attention is paid to the participatory approach of identifying reasons for inefficiency and developing counteracting measures, where employees and other relevant stakeholders are integrated into identification and change processes. The authors decided to apply the participatory concept for several reasons. The concept is suitable for transferring knowledge back and forth in this transdisciplinary collaboration between research and business. In addition, the participatory approach enables the development and implementation of company-specific food waste reduction measures as opposed to applying a predesigned concept that covers rather general measures and fails to consider company-specific needs. Moreover, the participatory approach integrates employees in decision-making processes, fostering their willingness to assume responsibility and enhancing their commitment to the project. The approach also strengthens communication among different business units, resulting in greater appreciation of each other's work.

The authors outline their experiences with the participatory approach and discuss its applicability for other organizations. Moreover, the authors also present a "Manual for Managers", which is a support tool for managers wishing to reduce food waste. This tool was developed based on the experiences gained in the pilot projects. The manual structures and summarizes the approaches applied in each step of the project phases.

\section{Article Structure}

The following article consists of four parts. The first part provides an overview of the food waste reduction projects that the authors originally developed for the participatory concept and of the methodology applied. The second part outlines the concept and the experiences gained during its application in the projects in greater detail. The third part consists of a discussion of the challenges faced in the projects, and, finally, in the fourth part, the authors present a Manual for Managers, which was developed based on the experiences gained. 


\section{Overview of the Projects and Methodology Applied}

The participatory concept, as a means to reduce food waste, was developed and applied in three projects by the iSuN between 2012 and 2015. The aim of all projects was to reduce food waste and food losses on both the production and consumer level.

The methodology applied in the projects employed different qualitative and quantitative methods (see Figure 1), selected on the basis of their suitability for the transdisciplinary collaboration between the research institute and the businesses involved. The methodology is designed to complete the tasks of data generation and analysis as well as to facilitate the joint development and implementation of measures to reduce food waste with the relevant stakeholders. The methods foster transdisciplinary exchange between researchers and employees as well as among employees of different business units. The participatory concept was derived from the research methodology and the experiences gained by the authors in the projects.

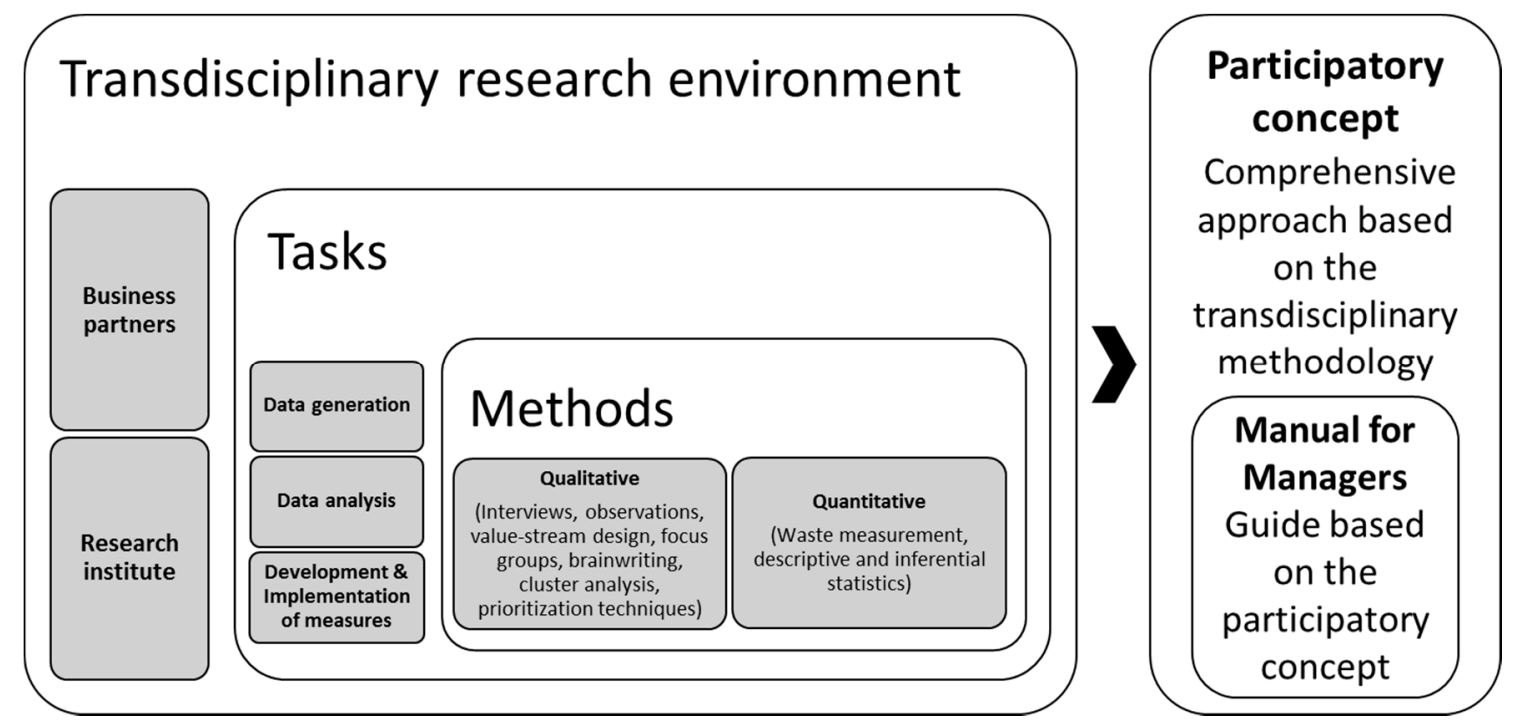

Figure 1. Methodology for the projects of reducing food waste and the resulting participatory concept and Manual for Managers.

The Manual for Managers is a practically oriented summary tool of the participatory concept that can be used by managers or others wishing to initiate food waste reduction projects in their organizations. The following section gives an overview of the projects and the partners involved.

\section{(a) Reduction of food waste in public catering}

This study involved eight partners from industry for a project duration of two years (September 2012-August 2014). Five caterers (including the kitchens of a retirement home, a school, a hospital, a work center for the disabled, and a university dining hall) and three wholesalers took part in the study. The aim was to reduce food waste in public catering. For this project, it was important to select partner organizations that cover downstream parts of the supply chain (wholesalers and caterers) in order to jointly develop measures to ensure that food waste is not simply shifted from one part of the supply chain to another. Process analysis and quantitative measurements of food waste were conducted, and practicable solutions were developed to enable the institutions to operate more economically by saving on costs of production and disposal, by offering their customers fresh meals in sufficient quantities, and by reducing any unnecessary and irresponsible waste of resources. Close cooperation between caterers and wholesalers in the project allowed for the development of both practical and economically competitive as well as environmentally conscious solutions to the problems described. The project design included a waste management period in the catering companies before 
and after implementing measures against food waste. This measurement was completed in four of the five catering facilities, since, in the meantime, one organization dropped out of the project [19].

\section{(b) Reduction of food loss for bread and bakery products}

This project involved six bakeries, the Chamber of Trades, bakery guilds, a consultant, and several bakery suppliers, as well as bakers' associations. It was financed for a duration of two years (December 2012-November 2014) and focused on delivering industry-specific and product-specific solutions for the reduction of food loss. Special attention was paid to the interaction between bakeries/retailers on the one hand, and consumers on the other. Partners were chosen to represent the different stakeholders of the bakery industry. Due to time constraints, the project conception only completed Phases 1, 2, and 3 (see Figure 2) of the participatory approach [20].

\section{(c) Reduction of food waste in healthcare organizations}

In this binational project (July 2013-December 2014), researchers studied German and Dutch caterers in healthcare organizations in order to improve resource efficiency on the supplier side and satisfaction with meals on the customer side. The project partners consisted of three hospitals and two retirement homes. In line with the requirements of the funding program, all of the partner organizations chosen were located in the Dutch-German border region Euregio Rhine-Waal. Processes along the food value chain were studied and improved in order to reduce food waste. In addition to the material flows, the project also investigated communication flows to enhance communication of the various employee groups associated with food supply [21].

\section{The Five-Phase Concept to Encounter Food Waste in a Participatory Approach}

\subsection{Overview of the Participatory Concept}

The participatory concept was developed by the authors in the context of three projects which all had the goal of reducing food waste (see Section 4). This particular five-phase concept is adapted to the phases of a PDCA (Plan-Do-Check-Act) cycle, also known as a Deming cycle or Shewhart cycle [22]. It consists of five major phases (see Figure 2) and represents a continuous improvement process (CIP) applied in Total Quality Management (TQM) [23]. TQM deals with the continuous efforts undertaken by a company's management to improve the quality of their products and services. In the process, TQM distributes responsibility so that it achieves a certain level of quality among all employees associated with the product or service. In addition, TQM is a customer focused approach that considers customers' needs and constantly strives to adjust the quality of the product or service to the identified needs [23]. In line with the requirements of TQM, the authors of this article sought to exploit the knowledge and experience of the groups involved. They integrated these employees into the process of developing and implementing measures to counteract food waste. Therefore, it made sense to adopt the well-known PDCA cycle and integrate participatory elements.

The roots of participatory management go back to Frederik Taylor, who sought to improve efficiency of the job in the late 1800s [24], and Elton Mayo, who conducted the Hawthorne studies on productivity and working conditions at the Western Electric telephone manufacturing factory from 1924 to 1933 [25]. Since then, diverse literature on employee/stakeholder involvement, or industrial democracy, has been published. In the 1980s and 1990s, researchers started to focus on employee motivation, productivity, and innovativeness, with the aim of providing businesses with a competitive advantage [26]. In recent studies, the scope of participatory management has been extended to projects involving multiple stakeholders. For this reason, a large number of studies applying participatory management can be found in the field of environmental sciences, where the natural and the human system is linked and different groups expand on mutually agreed solutions in a bid to protect the environment $[27,28]$. Nutrition and health sciences is another field where participatory management is applied, as researchers need to understand patients' habits and attitudes in order to identify and offer adequate solutions [29]. No reports on the participatory concept can be found in the current 
literature on food waste. By applying the participatory concept, the authors address the need for a comprehensive solution that integrates the technical food production system and the (human) stakeholders involved in the process of food production and consumption in order to counteract the problem of food waste.

As can be seen in Figure 2, the five phases of the cycle include a total of eleven consecutive steps, which either require being executed by project management alone or together with the relevant staff members (participatory elements).

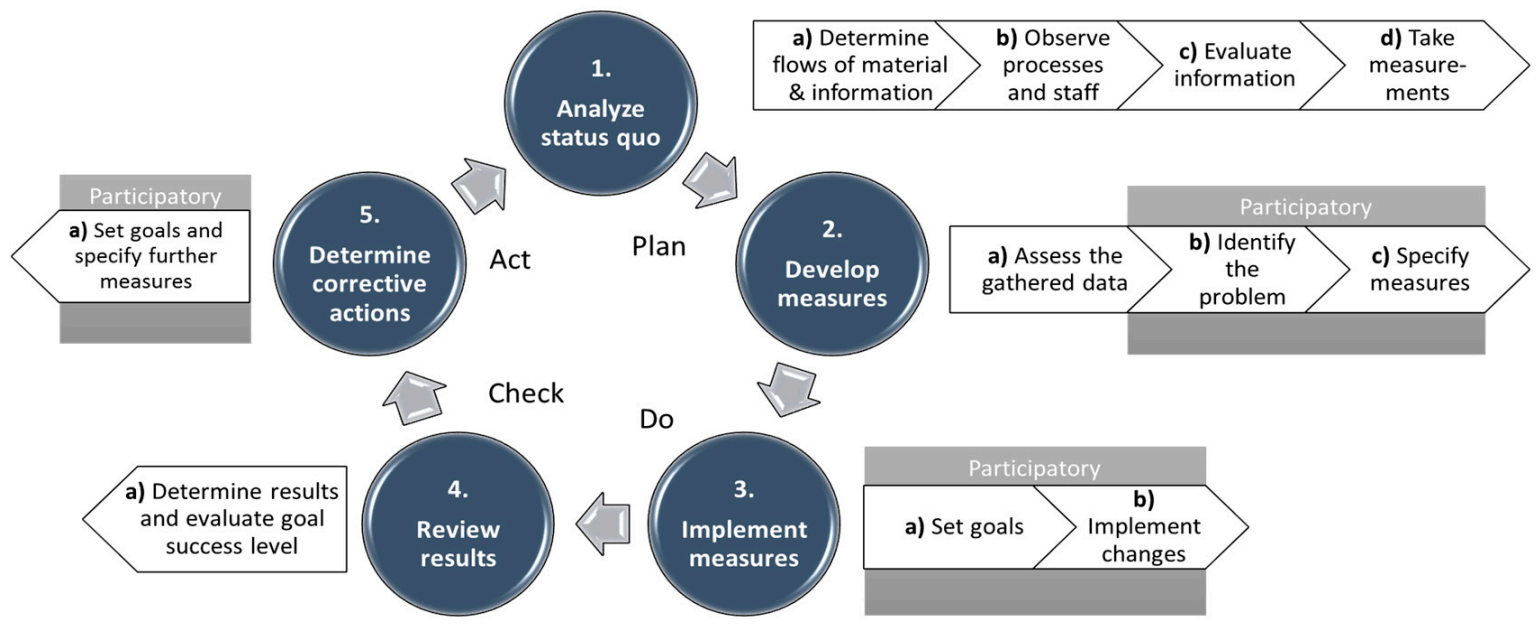

Figure 2. Project phases and analogy to PDCA (Plan-Do-Check-Act) cycle.

Generally, Phase 1 can be repeated after completing the first cycle, pursuing a continuous improvement process. Figure 2 provides an overview of the steps required in each of the five project phases. The first phase "Analysis of the status quo" means understanding the organization and the processes of interest and identifying organizational weaknesses with regard to the occurrence of food waste. In the second phase, a participatory approach is used for the "development of measures" to counteract wasting food as well as in the third phase, which is the "implementation of measures" part. The fourth phase comprises a "review of the results", after which the fifth phase, "evaluation and correction", follows, where the effectiveness of the measures is assessed with regard to the goals set previously, and corrective actions are specified, again using a participatory approach. The following Sections 5.2-5.6 present the concept and the methodology applied in greater detail.

\subsection{Phase 1: Analysis of the Status Quo}

The aim of Phase 1 is to provide an overall picture of the organization with the relevant processes and structures affecting food waste. This refers to the "Plan" phase of the PDCA cycle (see Figure 2). This phase is subdivided into a collection phase, where facts regarding the flows of information and material are gathered, an observation phase, where processes and staff behavior are observed, and a measurement phase, where the quantities of food waste are determined.

\section{(a) Determination of information and material flows}

The starting point of this step is a process analysis. The aim is to gather as much information as possible on those organizational structures and processes affecting the occurrence of food waste. This phase employs the methods of survey research and document analysis. Data on processes and structures is obtained by using organization-specific questionnaires and by analyzing the documents provided by the company management (waste records, floor plans, quality documents, etc.) in order to get a comprehensive view of organizational structures as well as of operational and supporting processes. As opposed to a material flow analysis, which quantitatively balances all masses, the 
material flow referred to in this context presents a qualitative description of the flow of material from the delivery of raw material to the distribution and/or consumption of the finished products.

In the projects, the responsible contact person of the partner institution was asked to fill in the questionnaires before an on-site visit was conducted by the researchers. If the information was not obtained in advance, the relevant information was gathered in the form of an interview.

\section{(b) Observation of processes and staff behavior}

This phase focuses on completing a fuller picture of the relevant operational and supporting processes and structures of the organization. The methods of participant observation and interviewing were applied [30]. By observing processes and staff behavior, researchers can get an impression of the working atmosphere, habits and attitudes of staff, and the attitudes of particular employees can also be recognized. Furthermore, differences between defined and actual processes are identified.

In the projects for this study, researchers visited the partner organizations in order to complete participant observation and the interviews. The researchers observed relevant processes and interviewed staff members in order to complete the picture and to verify the previously gathered information.

\section{(c) Evaluation of information}

The aim of this step is to reduce the complexity of the information collected through the document analysis, the survey, the interviews, and the observation. The condensed information serves as the basis for all of the following steps. Since it delivers facts about the handling of material and about product-related services (e.g., the serving of meals), it is necessary for planning the measurement process.

For these projects, the researchers used flowcharts based on the value-stream design by Erlach [31] to graphically present structures and processes, including material and information flows. Moreover, findings such as employees' special attitudes or discrepancies observed between the information provided and the actual state were documented.

\section{(d) Taking of measurements}

In this step, the quantities and the composition of the food waste occurring at the different stages of the value chain in relation to the food produced are determined either by exact weighing with electronic scales, by visual estimation as done by Kandiah et al. [32] and Martins et al. [33], or by counting and calculating the quantity of food wasted. The amount of food produced is either weighed electronically, calculated according to the organization's ERP (Enterprise Resource Planning) system, obtained from the manager's documentation, or taken from suppliers' delivery notes, depending on the availability of data. Descriptive statistics is used to summarize the results of the measurements. The measurement period needs to be set so as to deliver a representative sample of results for the occurrence of food waste. In a catering company, for example, the measurement period needs to represent its customers' average eating and food waste-producing behavior. For this reason, bank holidays and vacation periods should not be included in the measurement phase. In addition, it needs to be verified, especially in health-care organizations, that there was no mass outbreak of disease during the measurement period, which would lead to irregular values. Measurements are planned in light of the preliminary analysis phase. A lack of forecasting accuracy and demand variation lead to food waste. For instance, caterers dealing with a varying number of guests may produce serving losses. Mismanagement of stock may result in storage losses. Therefore, before any measurements can be conducted, relevant waste categories, such as storage, production, or serving losses, overproduction, or plate waste, must be identified in order to determine where in the organization measurement stations should be installed. The values obtained from the measurement and corresponding statistical analysis deliver relevant inputs for the development of corrective measures in subsequent steps.

In the projects for this study, relevant waste categories of interest included storage, production, or serving losses, overproduction, or plate waste. Moreover, waste was subdivided into food classes as done by Betz et al. [34] in order to reveal the components which contributed most to 
food waste. The food classes applied were individually chosen for each institution. While in one organization, processes enabled waste to be separated into the food classes meat/fish/egg-based components, starch-based components, vegetable/salad, dessert, non-avoidable, and miscellaneous, in another organization, only two food classes (miscellaneous and packaged food) were determined. The researchers transferred the values obtained during the measurement to MS Excel 2013 and IBM SPSS Statistics (Version 20.0. for Windows, IBM Corp., Armonk, NY, USA). They obtained a wide range of data; for example, lunch caused $62 \%$ of the food wasted, dinner $22 \%$, and breakfast $16 \%$. From this data, the researchers could determine that among all meals, lunch offered the greatest potential for the reduction of food waste.

\subsection{Phase 2: Development of Measures}

This phase constitutes the second part of the "Plan" phase of the PDCA cycle (see Figure 2) with the aim of developing and prioritizing measures to reduce food waste. It applies a participatory approach. Participation or participatory management means including employees in decision-making. In other words, contributing to the decision-making process is not limited to those who have formal power positions, but instead influence is shared with the rest of the members in the organization [35]. Decision-making in a participatory approach is a process, as opposed to the single act of choosing an option [36].

The development of reasonable measures and their subsequent implementation requires an understanding of employees' decision-making processes as well as an understanding of the change processes occurring in an organization. The first premise in order to generate employee enthusiasm and commitment is to create awareness of the problem - the employees need to decide if a problem is worth solving in the first place. Therefore, it is helpful to understand the decision-making process, which is used in the subsequent steps. Ford and Fottler [37] divided this process into the following phases, which help to address a given problem: (a) the intelligence phase where the problem is identified; (b) the conception phase where measures or alternatives are determined; and (c) the implementation phase where changes are applied in practice.

The aforementioned phases of the decision-making process (a), (b), and (c) are integrated into the five-phase concept (see Section 5). Phase 2 incorporates the intelligence phase (a), with the step "Identify the problem" and the conception phase (b), with the step "Specify measures". Finally, the implementation phase (c) is included in Phase 3 as the step "Implement changes".

Figure 3 illustrates how the decision-making phases were incorporated into the project design with the partner institutions.

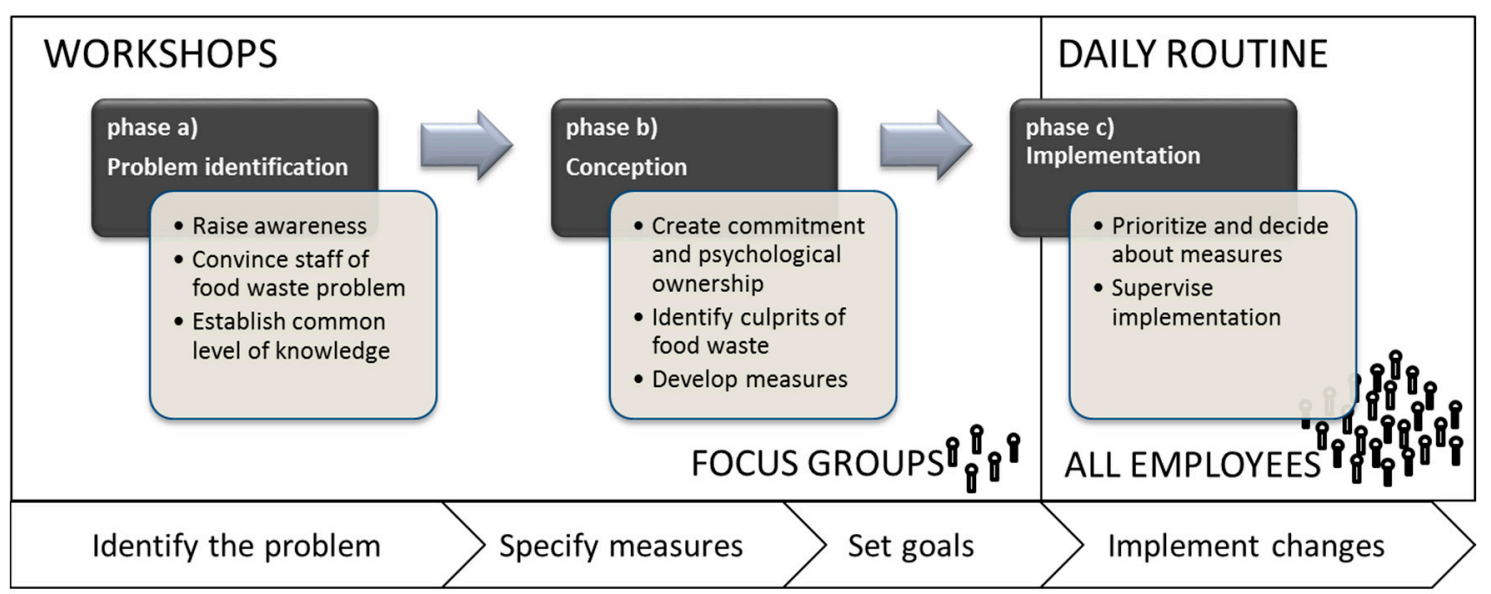

Figure 3. Application of the decision-making process [37] to integrate all relevant groups of employees into the participatory approach. 


\section{(a) Assessment of gathered data}

In this step, all the information gathered in "Section 5.2. Phase 1: Analysis of the Status Quo" is evaluated with the goal of identifying the relevant processes and structures which affect the occurrence of food waste, as well as the relevant staff members who need to be integrated into the further steps. Specific employees are identified whose experience may be beneficial to the development and implementation of measures. It is necessary to identify key actors in each department who can use their knowledge and experience to contribute to the process of developing corrective measures. When creating teams, hierarchical divisions should be ignored. Experience from the operations staff is as valuable as knowledge from management staff. While the latter group may be able to contribute with their knowledge on strategic decision-making, the first group has important detailed knowledge on operational processes in daily work routines.

The following key questions need to be answered before proceeding to the next step:

- What are the relevant core and supporting processes in the organization affecting the occurrence of food waste and what are the underlying organizational constraints (amount and qualification of staff; hierarchies; communication channels; cost structures; technical equipment; legal, political, or strategic constraints)?

- Do the observations and interviews coincide with the theoretical processes or does practical execution differ?

- Which departments and groups of employees are involved in the relevant processes and should they be involved in the process of developing measures?

- Are there specific employees whose experience could be beneficial for the development and implementation of measures?

- What are the key figures revealed by the measurement (e.g., quantities of material used and produced, relevant waste categories, waste ratios, financial impact of waste production)?

In the projects, the flowcharts prepared in Phase 1 presented information on the flows of material and information in a clear and well-arranged way. They demonstrated the operational and supporting processes along the value chain, and revealed departmental interactions within the organization. Based on observations and interviews, it was possible to identify differences between the theoretical process description and its practical execution. The findings also included information on the qualification of staff, the working hours available, the technical equipment, the communication structures, and the cost structure; all this needed to be kept in mind during the following steps. Measurements of the waste also delivered information on efficiency with regard to the use of raw materials. It showed how much food was used to produce one product unit. For example, the first measurement in one catering organization revealed that the product unit "breakfast" weighed $301 \mathrm{~g}$ on average, whereas in the second measurement, the weight fell to $251 \mathrm{~g}$. Moreover, due to the separation into food classes and waste categories, it revealed how much waste was produced, where in the value chain it occurred, and what it was composed of. For example, if the figures reveal that plate waste in a canteen is relatively high compared to other waste categories, this may be an indication that the quality of the food being served is inadequate or that portions are too large. On the other hand, high serving losses are an indicator of inaccurate demand planning.

\section{(b) Problem identification}

This step is dedicated to raising employees' awareness of the topic of food waste. The topic is introduced to the relevant employees (see Figure 3). Here, the process analyses and the waste measurements from previous steps provide valuable information which is intended to ensure that employees understand the necessity of improving resource efficiency. Since a participatory approach, relying on the employees to be key actors in developing measures to reduce food waste, is used, it is crucial to effectively convince them that a problem exists. 
The relevant staff members were integrated into the project in workshops with focus groups [38]. The concept of focus groups is adapted from qualitative marketing research, where it has been used to obtain knowledge on customer motivation, attitudes, and expectations [39]. It is a means to identify, describe, and understand psychological and sociological interrelation [40]. While in marketing research, interviews with focus groups are used to gain deeper insight into customer attitudes, in our case, focus groups revealed the attitudes of the various groups of employees (e.g., nurses vs. food order-taking assistants) about the topic of food waste as well as group attitudes about the work performed by other groups. Moreover, it delivered deeper insights into the way the different groups of employees interact and allowed the researchers to benefit from the knowledge and expertise of the employees involved.

\section{(c) Specification of measures}

During this step, the focus groups develop measures to counteract food waste. This part refers to the conception phase of the decision-making process. The employees should independently identify problematic processes in their daily work routines, and develop measures to counter these problems. The employees therefore participate in identifying problems within their daily work routines. Actual daily work routines may substantially differ from standard operating procedures for several reasons, such as ignorance or a suboptimal internal customer-supplier relationship between employees from two departments that nevertheless interact. Identifying these problems is the first step in the chain of initiating changes. Measures need to be tailored specifically to the working environment and the employee groups concerned with it. During the projects, workshops were held where the project participants used brainwriting to collect issues and ideas concerning food waste [41]. The results were categorized and refined, and led to the identification of key points to focus on. The participants agreed upon prioritization after discussing and assessing the importance of each aspect. Finally, employees and management jointly developed and prioritized measures to counteract food waste.

In a participatory approach, it is important that the project leaders stick to the principles of self-support and process orientation [42], which means that the participants are not influenced during the workshops and directed towards a particular solution. The participants need to be encouraged to present their own ideas rather than have pre-prepared thoughts and solutions imposed upon them.

\subsection{Phase 3: Implementation of Measures}

The aim of this phase, which represents the "Do" phase of the PDCA cycle (see Figure 2), is to help participants to determine specific goals to reach and to implement the measures they have developed earlier. In order to achieve sustainable results during the implementation phase, it is important to understand the stages of organizational change. Robbins [43] describes the stages of organizational change by using Lewin's Three Step Model: unfreezing, movement, and refreezing. In our case, "unfreezing" the present situation means identifying root causes and developing measures. Employees need to leave the equilibrium state, which is their daily work routines. During the movement step, the participants develop and implement options for change. Change requires driving forces, which direct behavior away from the status quo. Once measures are successfully implemented, the refreezing step starts, i.e., the changes are adopted into daily work life. The employees should become highly committed to the project; this can be achieved by creating psychological ownership. This is critical to generating true enthusiasm and commitment to the project [44]. If employees themselves develop the measures, they are more likely to overcome personal reservations about the changes. This means that they rather identify with the measures, thus improving the implementation and achieving sustainable results.

\section{(a) Goal setting}

It is essential to define the goals that are to be achieved. The more precise the goals are, the more specifically they can be addressed. Goals should also be operational, which means they are clearly defined in terms of their three dimensions of content, time, and extent, and it is important that the 
three dimensions for each goal are set at the beginning of the project. Goals may be subdivided into quantitative and qualitative goals. Quantitative goals can be measured. They relate to the key figures determined by the reference measurement, such as "reducing average food waste from $32 \%$ to less than $25 \%$ ", "decreasing the raw materials needed per produced unit by $10 \%$ ", or "decreasing lunch serving losses by $25 \%$ ". Management may also decide to set qualitative goals, such as "improving communication between departments $x$ and $y^{\prime \prime}$. Evaluating the achievement of qualitative goals is more difficult than for quantitative goals, since there is no key figure presenting the progress. Management, therefore, needs to set standards in order to make qualitative goals observable. Table 1 provides an example of a qualitative goal and an option for making it observable.

Table 1. Sample for the evaluation of a qualitative goal by a survey.

\begin{tabular}{|c|c|c|}
\hline $\begin{array}{l}\text { Possible Aspects to Evaluate the } \\
\text { Goal "Improve Communication" }\end{array}$ & Survey & Required Standard \\
\hline $\begin{array}{l}\text { Provision of completed lists on } \\
\text { patients' nutritional status } \\
\text { (transfer of information from } \\
\text { nurses to menu assistants) }\end{array}$ & $\begin{array}{l}\text { How often are the completed lists with the } \\
\text { required information available? } \\
\text { - } 100 \% \text { (daily) } \\
\text { - } \quad 75 \% \text { of days } \\
\text { - } \quad 50 \% \text { (every other day) } \\
\text { - } \quad 25 \% \text { of days } \\
\text { - } \quad 0 \% \text { (never) }\end{array}$ & e.g., $\min .75 \%$ \\
\hline $\begin{array}{l}\text { Delay in the order-taking process } \\
\text { due to incomplete lists on patient's } \\
\text { nutritional status }\end{array}$ & $\begin{array}{l}\text { What is the average delay per week caused } \\
\text { by incomplete lists? } \\
\text { - } \quad \text { More than one hour per week } \\
\text { - } \quad 40-60 \text { min per week } \\
\text { - } \quad 20-40 \text { min per week } \\
\text { - } \quad \text { Less than } 20 \text { min per week }\end{array}$ & e.g., max. $20-40 \mathrm{~min}$ \\
\hline Number of regular team meetings & $\begin{array}{l}\text { How often are team meetings held? } \\
\text { - } \quad \text { More than once per month } \\
\text { - } \quad \text { Monthly } \\
\text { - } \quad 6 \text { times per year } \\
\text { - } \quad 3 \text { times per year } \\
\text { - } \quad \text { Less than } 3 \text { times per year }\end{array}$ & e.g., min. 6 per year \\
\hline $\begin{array}{l}\text { Satisfaction of staff with } \\
\text { communication }\end{array}$ & $\begin{array}{l}\text { Do you agree that communication among } \\
\text { staff members is good: } \\
\text { - } \quad \text { Strongly disagree } \\
\text { - } \quad \text { Disagree } \\
\text { - } \quad \text { Neither agree nor disagree } \\
\text { - } \quad \text { Agree } \\
\text { - } \quad \text { Strongly agree }\end{array}$ & e.g., $\min .50 \%$ "agree" \\
\hline
\end{tabular}

\section{(b) Implementation of changes}

The point of this step is to decide on which of the prioritized measures to implement in order to reach the goals set in the preliminary step.

In the projects, this involved the focus groups jointly deciding on which measures to implement. This meant determining deadlines and actions, the employees in charge of each measure, and the timeline for implementation. All the information regarding the implementation was summarized in a project schedule and progress was also documented in the schedule. 
In the implementation phase, it is important to disseminate the measures developed to all relevant employees. The subsequent implementation of measures and the accordance with the schedule needs to be monitored, e.g., by interviewing the person in charge each month.

\subsection{Phase 4: Review of Results}

In the fourth phase, (see Figure 2), the goal is to review the current status in order to assess whether or not the goals were achieved. This phase refers to the "Check" phase of the PDCA cycle (see Figure 2).

\section{(a) Determination of results and evaluation of goal success level}

The necessary data is collected according to Phase 1 (see Section 5.2), i.e., by conducting an observation, an interview, or a measurement. Data recollection in the evaluation phase may be limited to data where goals have been set to allow for a comparison of results obtained and goals set. The data gathered is compared to the data obtained in Phase 1 at the beginning of the project, where quantitative and qualitative goals were set. For quantitative goals, the project managers assess as to whether changes in the key figures are considered statistically significant and whether or not the objectives have been achieved. For qualitative goals, there should be an analysis of whether or not the results coincide with the standards set.

\subsection{Phase 5: Determination of Corrective Actions}

The aim of the fifth phase, "Corrective actions", is to specify further actions that are necessary after assessing the degree of goal achievement in the preceding phase. This phase corresponds to the "Act" phase of the PDCA cycle (see Figure 2).

\section{(a) Goal setting and specification of further measures}

If the goals set are achieved, no corrective actions need to be specified. However, it is important to determine how performance beyond the project period can be continued, and whether or not it is realistic to expect further performance improvements. If the answer to this is positive, new standards need to be set. In cases where objectives are not achieved, the reasons for non-achievement need to be identified and corrective actions need to be specified. The question of which of the three goal dimensions - insufficient time, unclear content, or inappropriate extent - that has led to failure also must be answered. This can best be accomplished by integrating the relevant employees. They have implemented the measures in their daily work routines, and thus have gained valuable experience which can explain why the measures were successful or not. If corrective actions are specified, a new monitoring plan also needs to be established.

\section{Challenges Experienced with the Participatory Concept}

The participatory concept was applied in three projects (see Section 4). The following section describes the challenges experienced with the application of the concept in the cases under study.

- Gaining the support of management (management acting as a role model)

Management was very supportive in most organizations. In one catering company, however, management did not take the effort of reducing food waste seriously. Weighing lists in the first waste measurement period were not properly completed when the research team was not present. Moreover, comments were made in the workshops such as "It doesn't matter, it is only food waste", or "Our boss doesn't care anyway". This behavior demonstrated by employees reflected the management's attitude and revealed how important management support is. This catering company did not complete the project, but instead dropped out before any measures could be specified and implemented. 
- Using participation as a motivator

Many employees gave positive feedback as they were happy to be able to give input and present their ideas for reducing food waste. For them, it was important to have the workshops and the informal talks in between, since their daily work routines did not provide such a platform for exchange. However, there were also burdens regarding inter-departmental communication which needed to be overcome first in order to establish a level of trust among employees. In one hospital, there was a lack of communication between the menu assistants taking patients' orders and the nursing staff. As an example, the menu assistants thought that the nursing staff felt superior and were always too busy to provide them with the necessary information on the nutritional and health status of special patients. However, the nursing staff were unaware of the impression they gave. By bringing the different groups of employees together, appreciation of the other group's work was enhanced, dissatisfaction decreased, and measures were developed jointly.

- Dealing with the diversity of the target group and raising employee awareness

Raising awareness for the topic of food waste is crucial, as it influences employees' commitment and motivation to participate. The challenge was to convince all groups of employees that it was worth committing to the projects. While the pure presentation of facts and figures of quantities and associated costs of the food wasted were convincing for managers, the other groups of employees or customers needed to be addressed in a different way. For this reason, the presentation of facts was adapted to the respective target groups. As an example, in order to demonstrate the amount of food wasted in a retirement home, a more descriptive style of language (as well as images) was applied to present the results to the residents than was used to present the same facts to the management.

- Dealing with the limited time constraints

Although most employees were willing to support the projects, time in the partner organizations was often a limiting factor. Since the employees were busy with their daily work routines, it was important to offer them predesigned support tools. These tools facilitated the implementation of measures. Examples of such tools included weighing lists for waste measurements, waste calculators for catering companies, and training material for bakery sales staff.

\section{A Manual for Managers}

The participatory concept was developed for the projects presented in Section 4. It consists of five phases, which comprise eleven consecutive steps (see Section 5). Based on the experience gained from the projects, the authors developed the following Manual for Managers (see Table 2). It summarizes the approaches applied by the researchers in the different steps and illustrates how the results of each step can be documented. It also lists the goal of each step and thus brings to mind why the different tasks need to be accomplished. This guide is a food waste reduction tool and can be applied by managers or researchers wishing to combat the waste of food in an organization. It facilitates the application of the participatory concept and helps managers to complete the relevant steps one by one. Managers themselves may have become blind to shortcomings in their own company processes. Therefore, applying this guide will enable them to scrutinize existing processes and get a more holistic view of their organization. 
Table 2. Manual for Managers: A step-by-step guide for the application of the participatory approach to combat food waste (overview of project phases, approaches applied, and results obtained).

\begin{tabular}{|c|c|c|c|}
\hline Step & Optional Approaches & Aim of the Approach & Documentation \\
\hline \multicolumn{4}{|c|}{ Analyze current state } \\
\hline $\begin{array}{l}\text { (a) Determine material \& } \\
\text { information flows }\end{array}$ & $\begin{array}{l}\text { Interviews and questionnaires related to processes } \\
\text { (flows of information and material) }\end{array}$ & $\begin{array}{l}\text { Understanding relevant operational and } \\
\text { supporting processes }\end{array}$ & $\begin{array}{l}\text { Completed questionnaires } \\
\text { Quality documents } \\
\text { Data records } \\
\text { Waste records } \\
\text { Floor plans } \\
\end{array}$ \\
\hline $\begin{array}{l}\text { (b) Observe processes and } \\
\text { staff behavior }\end{array}$ & Observations & $\begin{array}{l}\text { Receiving information on structures and processes } \\
\text { Gaining experience about the working atmosphere, habits } \\
\text { and attitudes of staff, recognizing particular } \\
\text { employees' attitudes } \\
\text { Detecting differences between defined and } \\
\text { actual processes }\end{array}$ & Notes of observation \\
\hline (c) Evaluate information & Processing of information by value-stream design [31] & $\begin{array}{l}\text { Structuring the information gathered } \\
\text { Reducing complexity of the information }\end{array}$ & Material and information flow charts \\
\hline (d) Take measurements & $\begin{array}{l}\text { Classification of food produced and wasted into } \\
\text { relevant food classes and waste categories } \\
\text { Determination of quantities of food produced and } \\
\text { wasted by weighing, visual estimation, or processing } \\
\text { of production figures from the ERP system, or other } \\
\text { quantity documentation (e.g., delivery notes) } \\
\text { Statistical analysis of data }\end{array}$ & $\begin{array}{l}\text { Obtaining knowledge on the quantities produced and on } \\
\text { the percentage wasted } \\
\text { Providing facts and figures for economic evaluation } \\
\text { Identifying food classes and waste categories to focus on }\end{array}$ & $\begin{array}{l}\text { Various production and waste figures (e.g., total } \\
\text { production volume and waste, average waste, } \\
\text { average waste per person, average produced } \\
\text { quantity per day or per person, average waste } \\
\text { per food class or per waste category) }\end{array}$ \\
\hline \multicolumn{4}{|c|}{ Develop measures } \\
\hline (a) Assess the gathered data & $\begin{array}{l}\text { Waste measurement analysis } \\
\text { Assessment of documentation received } \\
\text { Comparison of theoretical processes with } \\
\text { observations made } \\
\text { Answering of key questions }\end{array}$ & $\begin{array}{l}\text { Identifying weaknesses along the value chain with regard } \\
\text { to the transfer of material and information } \\
\text { Determining relevant processes to focus on } \\
\text { Identifying departmental interfaces and selecting staff for } \\
\text { focus groups }\end{array}$ & $\begin{array}{l}\text { Documentation of findings } \\
\text { List of participants for focus groups }\end{array}$ \\
\hline (b) Identify problem & $\begin{array}{l}\text { Workshop with focus group, phase a) (see Figure } 3 \text { ) } \\
\text { Presentation of facts and figures }\end{array}$ & $\begin{array}{l}\text { Creating awareness of the problem } \\
\text { Motivating employees }\end{array}$ & Minutes of the workshop \\
\hline (c) Specify measures & $\begin{array}{l}\text { Workshop with focus group, phase b) (see Figure 3) } \\
\text { Brainwriting } \\
\text { Clustering of ideas } \\
\text { Joint development of measures }\end{array}$ & $\begin{array}{l}\text { Achieving participation of relevant employees } \\
\text { Identifying key points for food waste based on } \\
\text { employees' perspective } \\
\text { Creating commitment and psychological ownership } \\
\text { Developing measures }\end{array}$ & $\begin{array}{l}\text { Minutes of workshop } \\
\text { Photo documentation of results }\end{array}$ \\
\hline
\end{tabular}


Table 2. Cont.

\begin{tabular}{|c|c|c|c|}
\hline Step & Optional Approaches & Aim of the Approach & Documentation \\
\hline \multicolumn{4}{|c|}{ Implement measures } \\
\hline (a) Set goals & $\begin{array}{l}\text { Analysis of qualitative goals and identification of } \\
\text { measureable elements } \\
\text { Determination of standards that should be targeted } \\
\text { for quantitative and qualitative goals }\end{array}$ & $\begin{array}{l}\text { Making qualitative results measurable } \\
\text { Setting goals to give emphasis to the project } \\
\text { Defining the basis for development of measures }\end{array}$ & Documentation of goals \\
\hline (b) Implement changes & $\begin{array}{l}\text { Workshop with focus group, (phase c) (see Figure 3) } \\
\text { Selection of measures to implement } \\
\text { Democratic prioritization of measures by participants } \\
\text { (e.g., "low hanging fruits first") } \\
\text { Setting of timeline and to-do list, definition of } \\
\text { employees in charge } \\
\text { Implementation of measures into daily work routines } \\
\text { Transfer into practice (all employees) }\end{array}$ & $\begin{array}{l}\text { Jointly choosing and prioritizing measures to implement } \\
\text { in order to increase acceptability and to create ownership } \\
\text { Setting a timeline and to-do list, defining employees in } \\
\text { charge to assure timely implementation and to set up } \\
\text { project schedule } \\
\text { Transferring workshop results into practice to achieve the } \\
\text { goals set }\end{array}$ & $\begin{array}{l}\text { Project schedule/catalog of measures } \\
\text { Minutes of workshop } \\
\text { Revised process descriptions }\end{array}$ \\
\hline \multicolumn{4}{|c|}{ Review results } \\
\hline $\begin{array}{l}\text { (a) Determine results and } \\
\text { evaluate degree of goal } \\
\text { success level }\end{array}$ & $\begin{array}{l}\text { Observations } \\
\text { Interviews } \\
\text { Measurement of production volume and food waste } \\
\text { Questionnaires to assess qualitative goals } \\
\text { Comparison of reference and control data for } \\
\text { qualitative and quantitative goals }\end{array}$ & $\begin{array}{l}\text { Examining and documenting new current situation } \\
\text { Determining whether or not goals were achieved } \\
\text { Determining if measures were successful }\end{array}$ & $\begin{array}{l}\text { Documentation of observations and interviews } \\
\text { Completed questionnaires } \\
\text { Weighing lists } \\
\text { Documentation of key figures before and after } \\
\text { implementation of measures } \\
\text { Reports on goal achievement }\end{array}$ \\
\hline \multicolumn{4}{|c|}{ Determine corrective actions } \\
\hline $\begin{array}{l}\text { (a) Set goals and specify } \\
\text { further measures }\end{array}$ & $\begin{array}{l}\text { If goals were not achieved: analysis of reasons and } \\
\text { return to Phase } 2\end{array}$ & $\begin{array}{l}\text { Assessing how realistic the goals set were and } \\
\text { determining new goals } \\
\text { Understanding why goals were not achieved and altering } \\
\text { measures accordingly }\end{array}$ & $\begin{array}{l}\text { Documentation of analysis } \\
\text { Revised project schedule/catalog of measures }\end{array}$ \\
\hline
\end{tabular}




\section{Discussion}

The reasons for food waste on the manufacturing and retail level, as well as in the catering industry, have been widely discussed $[5,6,18,20,45-56]$. Exceeding internal sell-by dates and varying demand often lead to the wastage of food $[6,46,57]$. Counteractive measures, such as efficient demand planning and improved forecasting accuracy, have been proposed in order to avoid such losses. Technical solutions already exist. Examples include intelligent food logistics (e.g., smart distribution practices such as FEFO, first expired first out) [58], and predictive analysis used for machine learning [59], which may result in the more efficient handling of food products along the value chain. However, the food value chain is a sociotechnical system in which machines and people work hand in hand to produce food and related services. Hence, technical solutions address only one side of the system, whereas comprehensive approaches additionally integrate the relevant stakeholders (employees, customers, etc.) into the optimization process. To this end, it does not suffice to merely raise people's awareness of the topic of food waste. Rather, they must be integrated into the challenging task of developing and implementing measures to combat food waste. The participatory concept applied in this study addresses the need for a comprehensive solution.

With the participatory concept, significant reductions of up to $39 \%$ of the food wasted could be reached in five partner organizations $[19,21]$. Hence, the concept contributes to meeting the Sustainable Development Goal (SGD 12.3) the EU and Member States have committed to which means halving per capita food waste at the retail and consumer level by 2030, and reducing food losses along the food production and value chain [60].

The majority of the 377,000 food companies in Germany, including the crafts sector, industry, retailers, and large-scale consumers, are classified as SMEs (small and medium-sized enterprises) [61]. The quantity of food wasted by these companies amounts to 8.59 million tons annually [1]. The companies compete on a highly competitive market, as the five biggest food retailers in Germany have a market share of more than 70\% [62]. Considering the strong competition on the market, these SMEs face a situation of high cost pressures, often leading to low staff capacities and time constraints which hinder the implementation of food waste reduction projects. Research also confirmed that the companies that implemented the participatory projects discussed in this paper-all of them SMEs themselves-also have a high workload, which leaves them little room for extra projects outside of their daily work routines. The companies require assistance and easy access to support tools in order to complete food waste reduction projects.

Therefore, the participatory concept with its Manual for Managers (see Section 7) provides useful assistance for such SMEs with its systematic approach to fight food waste. Managers are guided to complete the project one step at a time, yet the results can reveal inefficiencies in core and supporting processes. A food waste reduction strategy which uses the participatory concept could be integrated as part of the TQM approach of a company. However, no food waste reduction tool and no management system will lead to the desired outcome if it is not supported by the top management. Organizations announcing the reduction of food waste as one of their goals solely for publicity reasons are likely to fail if the corresponding strategic approach is missing. In order to be successful, top management must formulate a strategy, inspire employees, live the system, and assign the required resources.

Another advantage of the concept presented here is its participatory approach, which makes use of experience and knowledge. The authors' experiences with the participatory concept correspond with those of other authors who have also applied a participatory approach. They likewise found that commitment and trust increased following stakeholder participation $[63,64]$ and experienced the participatory approach as a useful method for capturing the knowledge and experiences [29] of different groups of employees along the food value chain. Moreover, they described the participatory approach as being capable of reducing internal conflicts among individuals [65]. This advantage was also perceived by the authors of this article, who found that participation helped groups to gain a better understanding of other groups' work. The participatory approach scrutinizes existing structures of communication and supports the personal exchange of different intra-organizational units. 
Where employees with different functions, qualifications, and professional backgrounds physically or virtually meet, they need to understand each other and agree on the processes and actions to be taken.

However, reducing food waste in one company should not lead to the shifting of food waste to other parts of the value chain, such as to suppliers or customers [45]. Fighting food waste is not a matter of a single company. Furthermore, $14.2 \%$ of the food wasted in Germany occurs on the production level, whereas the major part (39.3\%) is produced by the end consumer [1]. Parry et al. [66] noted that it is necessary to integrate the consumer into food waste reduction efforts as well. Hence, initiatives aimed at decreasing food waste along the whole value chain need to shift the boundaries from an intra- to an inter-organizational level and involve all actors of the value chain [4,67]. The participatory concept takes account of this requirement by its application of focus groups that allow bringing together the multiple stakeholders of the food value chain. The cooperation of multi-stakeholders is also an approach supported by Halloran et al. [68] and Derqui et al. [69], who state that this could raise awareness of food waste. It is important to stimulate a debate on the quality of food to increase its appreciation. Only by doing so can goal conflicts, such as increasing revenues vs. wasting less on the consumer level, be resolved. In the context of food waste reduction, we therefore suggest referring to the term food value chain rather than to the food supply chain [70,71]. The process of supplying food means dealing with a set of values rather than solely with a foodstuff complying with a specification. If food waste reduction initiatives managed to create the added value of "low food waste", this could contribute to solving the goal conflicts existing among the different actors of the value chain.

\section{Conclusions}

With the participatory concept, it becomes possible to identify organizational weaknesses leading to the occurrence of food waste and to develop and implement measures to counteract food waste. On an organizational level, however, applying the concept is just the second step after gaining an understanding of the importance of the topic itself. This is where the limitations of the participatory concept lie. It requires that the management of a company is already aware of the problem of food waste and acts as an example. Future research should analyze how management can be convinced to commit to reducing food waste; it should also shed light on how to enhance employee motivation and commitment. Thereby, support of any group involved in a food waste reduction project can best be obtained by using language specific to a target group. Employees who are not used to giving feedback might be afraid of admitting the existence of problems. If employees are intimidated by the presence of superiors, they will not feel comfortable contributing their expertise. In this context, management should seek to establish a level of trust among the participating employees of all hierarchical levels.

Moreover, these studies have revealed that there are special burdens of communication at departmental interfaces where employees with different functions, qualifications, and professional backgrounds physically or virtually meet; they need to understand each other and agree on the processes and action to be taken. Future research should, therefore, focus on analyzing the flows of communication within an organization, especially those at the departmental interfaces having an influence on the occurrence of food waste.

For SMEs, the participatory approach and the Manual for Managers developed by the authors facilitate the execution of food waste reduction projects. However, the approach requires that employees and managers take the time to develop measures; it provides no predesigned solutions for counteracting food waste. Especially in SMEs, management and staff have major time constraints outside of their daily work routines. Those companies often do not have job positions exclusively dealing with quality management or sustainability issues. In addition to the above-mentioned manual, there are several other tools available on the internet that support the reduction of food waste. These instruments were often developed in academic research projects. It is crucial that SMEs have easy access to those instruments. Since SMEs in the food industry are the main target group of such instruments, future research should analyze how to best design the transfer of results from science to SME businesses. 
The participatory approach does not solve existing goal conflicts within a company or along the food value chain. In this context, it would be useful to create and disseminate the added value of "low food waste", as this would enable companies to benefit economically from the measures, encouraging them to participate in food waste reduction projects. Therefore, future research should analyze how the added value of "low food waste" can be generated and disseminated to all stakeholders in the food industry. Moreover, this would increase the level of appreciation for food, which is necessary to reduce food waste also at the consumer level.

Acknowledgments: The three research projects (a), (b), and (c) were funded by (a) the European Regional Development Fund (ERDF), the Ministry of Economic Affairs and Energy of North Rhine-Westphalia (NRW) (MWME), Ziel.2 NRW and Münster University of Applied Sciences (funding code 005-1111-0063), (b) by the Ministry for Climate Protection, Environment, Agriculture, Nature Conservation and Consumer Protection of the German State of North Rhine-Westphalia (MKULNV NRW) (funding code: Az 17-06.03.01-14/2012), and (c) by the European Regional Development Fund (ERDF) of the INTERREG IV A program, the Ministry for Climate Protection, Environment, Agriculture, Nature Conservation and Consumer Protection of the German State of North Rhine-Westphalia (MKULNV NRW), and the Dutch Provinces of North Brabant, Gelderland, and Limburg (funding code: “Duurzaam Gezond" III-1-03=018.10).

Author Contributions: All authors conceived the project design of the three pilot studies. Petra Teitscheid, Guido Ritter and Judith Kreyenschmidt supervised the work. Christina Strotmann, Christine Göbel and Silke Friedrich conducted the studies with the project partners and analyzed the data. Christina Strotmann wrote the paper. All authors critically revised and approved the final manuscript and contributed to the scientific content of the paper.

Conflicts of Interest: The authors declare no conflict of interest.

\section{Abbreviations}

The following abbreviations are used in this manuscript:

$\begin{array}{ll}\text { ERP } & \text { Enterprise Resource Planning } \\ \text { FAO } & \text { Food and Agriculture Organization } \\ \text { FEFO } & \text { First expired first out } \\ \text { IGD } & \text { Institute of Grocery Distribution } \\ \text { iSuN } & \text { Institute of Sustainable Nutrition } \\ \text { PDCA } & \text { Plan-Do-Check-Act } \\ \text { SME } & \text { Small and medium-sized enterprises } \\ \text { UN } & \text { United Nations } \\ \text { WRAP } & \text { Waste and Resources Action Programme } \\ \text { WRI } & \text { World Resource Institute }\end{array}$

\section{References}

1. Noleppa and Cartsburg. Das Große Wegschmeißen: Vom Acker bis zum Verbraucher: Ausmaß und Umwelteffekte der Lebensmittelverschwendung in Deutschland. 2015. Available online: https://www.wwf. de/fileadmin/fm-wwf/Publikationen-PDF/WWF_Studie_Das_grosse_Wegschmeissen.pdf (accessed on 8 November 2016). (In German)

2. Rückert-John, J. Natürlich Essen: Kantinen und Restaurants auf dem Weg zu Nachhaltiger Ernährung [Stuttgart-Hohenheim, Diss-Univ., 2006.], 1st ed.; Campus Verlag: Frankfurt am Main, Germany, 2007. (In German)

3. Katajajuuri, J.; Silvennoinen, K.; Hartikainen, H.; Heikkilä, L.; Reinikainen, A. Food waste in the Finnish food chain. J. Clean. Prod. 2014, 73, 322-329. [CrossRef]

4. Göbel, C.; Langen, N.; Blumenthal, A.; Teitscheid, P.; Ritter, G. Cutting Food Waste through Cooperation along the Food Supply Chain. Sustainability 2015, 7, 1429-1445. [CrossRef]

5. Kranert, M.; Hafner, G.; Barabosz, J.; Schuller, H.; Leverenz, D.; Kölbing, A.; Schneider, F.; Lebersorger, S. Determination of Discarded Food and Proposals for a Minimization of Food Wastage in Germany; Abridged Version; University Stuttgart Institute for Sanitary Engineering, Water, Quality and Solid Waste Management (iswa): Stuttgart, Germany, 2012; Available online: http:/ /www.bmelv.de/SharedDocs/Downloads/EN/Food/ Studie_Lebensmittelabfaelle_Kurzfassung.pdf?_blob=publicationFile (accessed on 26 September 2016).

6. Garrone, P.; Melacini, M.; Perego, A. Opening the black box of food waste reduction. Food Policy 2014, 46, 129-139. [CrossRef] 
7. Garrone, P.; Melacini, M.; Perego, A.; Sert, S. Reducing food waste in food manufacturing companies. J. Clean. Prod. 2016, 137, 1076-1085. [CrossRef]

8. Eriksson, M.; Strid, I.; Hansson, P. Waste of organic and conventional meat and dairy products-A case study from Swedish retail. Resour. Conserv. Recycl. 2014, 83, 44-52. [CrossRef]

9. Hanson, C.; Lipinski, B.; Robertson, K.; Dias, D.; Gavillan, I.; Gréverath, P.; Ritter, S.; Fonseca, J.; VanOtterdij, R.; Timmermans, T.; et al. Food Loss and Waste Accounting and Reporting Standard. 2016. Available online: http://www.wri.org/sites/default/files/REP_FLW_Standard.pdf?utm_campaign= FOOD_FLWProtocol\&utm_source=FLW_Protocol_Pub_Launch-2016-06-06\&utm_medium=email\&utm_ content $=$ title (accessed on 26 November 2016).

10. WRAP (Waste \& Resources Action Programme). Taking Action on Waste: The Business Case for Hospitality and Food. Available online: http:/ /www.wrap.org.uk/sites/files/wrap/Taking\%20action\%20on\%20waste\%3B\%20the $\% 20$ business \%20case \%20for\%20hospitality\%20and\%20food\%20service.pdf (accessed on 26 November 2016).

11. Measuring to Manage Resources and Wastes-An introduction. 2011. Available online: http://www. fccenvironment.co.uk/assets/files/pdf/content/measure-manage-resources.pdf (accessed on 26 September 2016).

12. Supply Chain Walk Problem Solving Tool. 2014. Available online: http://www.igd.com/Documents/Waste \%20Prevention/Supply_Chain_Walk_Problem_\%20Solving_Tool_v1.pdf (accessed on 26 September 2016).

13. United against Waste. Checkliste: Wo können Sie in Ihrem Betrieb Lebensmittelabfälle Vermeiden. Available online: http:/ / www.united-against-waste.de/downloads/dehoga-checkliste.pdf (accessed on 26 September 2016). (In German)

14. Unternehmens-Check. 2014. Available online: http://www.geniesstuns.de/wp-content/uploads/2014/ 10/20141029_J069-Lebensmittelcheck-Lebensmittelwirtschaft-2i-2.pdf (accessed on 26 September 2016). (In German)

15. FoodSave DIY Food Waste Audit. Available online: http://www.foodsave.org/wp-content/uploads/2014/ 09/FoodSaveDIYWasteAudit-fin.pdf (accessed on 26 September 2016).

16. Großküchen \& Lieferanten Lebensmittelverluste Gemeinsam Reduzieren: Leitfaden für das Küchenmanagement als Hilfestellung zum Ressourcenschutz. 2014. Available online: https://www.fh-muenster.de/isun/downloads / leitfaden-grosskuechen-lebensmittelabfaelle-vermeiden.pdf (accessed on 26 September 2016).

17. Strotmann, C.; Niepagenkemper, L.; Göbel, C.; Flügge, F.; Friedrich, S.; Ritter, G.; Kreyenschmidt, J. The LAV Platform-Preventing Food Waste in SMEs of the German Food Industry and the Hospitality Sector-The Participatory Development of an Online Toolbox of Instruments Encountering Food Waste and its Transfer into the Public. 2016; submitted.

18. Sonnino, R.; McWilliam, S. Food waste, catering practices and public procurement: A case study of hospital food systems in Wales. Food Policy 2011, 36, 823-829. [CrossRef]

19. Göbel, C.; Blumenthal, A.; Niepagenkemper, L.; Baumkötter, D.; Teitscheid, P.; Wetter, C. Reduktion von Warenverlusten und Warenvernichtung in der AHV_Ein Beitrag zur Steigerung der Ressourceneffizienz: Bericht zum Forschungs- und Entwicklungsprojekt; Institut für Nachhaltige Ernährung und Ernährungswirtschaft-iSuN: Münster, Germany, 2014; Available online: http:/ /www.hb.fh-muenster.de/opus/fhms/volltexte/2014/ 1057/ (accessed on 8 November 2016). (In German)

20. Ritter, G.; Friedrich, S.; Heitkönig, L. Reduktion von Lebensmittelabfällen bei Brot und Backwaren Ein Konzept für Handwerk, Handel und Verbraucher; Institute of Sustainable Nutrition (iSuN)L: Münster, Germany, 2015. (In German)

21. Teitscheid, P.; Strotmann, C.; Blumenthal, A.; Schreiner, L.; Aich, E. Forschungsbericht zum INTERREG Projekt "Nachhaltig Gesund/Duurzaam Gezond". 2015. Available online: https://www.fh-muenster.de/ isun/downloads/studie-lebensmittelverschwendung/Forschungsbericht_NachhaltigGesund_Deutsch_0705_latest.pdf (accessed on 26 September 2016). (In German)

22. Shewhart, W.A. Statistical Method from the Viewpoint of Quality Control; Dover Publications: New York, NY, USA, 1986.

23. Brüggemann, H.; Bremer, P. Grundlagen Qualitätsmanagement: Von den Werkzeugen Über Methoden zum TQM, 2nd ed.; Springer: Wiesbaden, Germany, 2015. (In German)

24. Shagholi, R.; Hussin, S. Participatory management: An opportunity for human resources in education. Procedia Soc. Behav. Sci. 2009, 2009, 1939-1943. [CrossRef]

25. Emmet, J.M. Participative Management-A Case Study: City of South Lake Tahoe. 2005. Available online: https:/ / www.calpelra.org/pdf/Emmett,\%20Janet.pdf (accessed on 8 December 2016). 
26. Branch, K.M. Chapter 10. Participative Management and Employee and Stakeholder Involvement. 2011. Available online: http://www.au.af.mil/au/awc/awcgate/doe/benchmark/ch10.pdf (accessed on 4 January 2017).

27. Reed, M.S. Stakeholder participation for environmental management: A literature review. Biol. Conserv. 2008, 141, 2417-2431. [CrossRef]

28. Martínez-Falero, E.; Martin-Fernandez, S.; Garcia-Abril, A. Quantitative Techniques in Participatory Forest Management; CRC Press: Boca Raton, FL, USA, 2013.

29. Cole-Lewis, H.J.; Smaldone, A.M.; Davidson, P.R.; Kukafka, R.; Tobin, J.N.; Cassells, A.; Mynatt, E.D.; Hripcsak, G.; Mamykina, L. Participatory approach to the development of a knowledge base for problem-solving in diabetes self-management. Int. J. Med. Inform. 2016, 85, 96-103. [CrossRef] [PubMed]

30. Nykiel, R.A. Handbook of Marketing Research Methodologies for Hospitality and Tourism; Routledge: New York, NY, USA, 2007.

31. Erlach, K. Wertstromdesign: Der Weg zur Schlanken Fabrik, 2nd ed.; Springer: Berlin, Germany, 2010. (In German)

32. Kandiah, J.; Stinnett, L.; Lutton, D. Visual Plate Waste in Hospitalized Patients: Length of Stay and Diet Order. J. Am. Diet. Assoc. 2006, 106, 1663-1666. [CrossRef] [PubMed]

33. Martins, M.L.; Cunha, L.M.; Rodrigues, S.S.; Rocha, A. Determination of plate waste in primary school lunches by weighing and visual estimation methods: A validation study. Waste Manag. 2014, 34, 1362-1368. [CrossRef] [PubMed]

34. Betz, A.; Buchli, J.; Göbel, C.; Müller, C. Food waste in the Swiss food service industry-Magnitude and potential for reduction. Waste Manag. 2015, 2015, 218-226. [CrossRef] [PubMed]

35. Del Val, M.P.; Lloyd, B. Measuring empowerment. Leadersh. Organ. Dev. J. 2003, 2003, 102-108. [CrossRef]

36. Pardo-del-Val, M.; Martínez-Fuentes, C.; Roig-Dobón, S. Participative Management and Its Influence on Organizational Change. Manag. Decis. 2012, 50, 1843-1860. [CrossRef]

37. Ford, R.C.; Fottler, M.D. Empowerment: A matter of degree. Acad. Manag. Executive 1995, 9, 21-29. [CrossRef]

38. Kauffeld, S. Nachhaltige Weiterbildung. Betriebliche Seminare und Trainings Entwickeln Erfolge Messen, Transfer Sichern; Springer: Heidelberg, Germany, 2010. (In German)

39. Kamenz, U. Marktforschung: Einführung mit Fallbeispielen, Aufgaben und Lösungen; Schäffer-Poeschel: Stuttgart, Germany, 2001. (In German)

40. Kepper, G. Methoden der qualitativen Marktforschung. In Handbuch Marktforschung: Methoden, Anwendungen, Praxisbeispiele, 3rd ed.; Herrmann, A., Homburg, C., Klarmann, M., Eds.; Gabler: Wiesbaden, Germany, 2008; pp. 175-212. (In German)

41. Klebert, K.; Schrader, E.; Straub, W.G. Moderations-Methode: Das Standardwerk, 3rd ed.; Windmühle: Hamburg, Germany, 2006. (In German)

42. Dittrich-Brauner, K.; Dittmann, E.; List, V.; Windisch, C. Interaktive Großgruppen: Change-Prozesse in Organisationen Gestalten, 2nd ed.; Springer: Berlin/Heidelberg, Germany, 2013. (In German)

43. Robbins, S.P. Organizational Behavior, 9th ed.; Prentice Hall: Upper Saddle River, NJ, USA, 2001.

44. Umble, M.; Umble, E. Overcoming resistance to change. Ind. Manag. 2014, 56, 16-21.

45. Engström, R.; Carlsson-Kanyama, A. Food losses in food service institutions: Examples from Sweden. Food Policy 2004, 29, 203-213. [CrossRef]

46. Lebersorger, S.; Schneider, F. Food loss rates at the food retail, influencing factors and reasons as a basis for waste prevention measures. Waste Manag. 2014, 34, 1911-1919. [CrossRef] [PubMed]

47. Mena, C.; Terry, L.A.; Williams, A.; Ellram, L. Causes of waste across multi-tier supply networks: Cases in the UK food sector. Int. J. Prod. Econ. 2014, 152, 144-158. [CrossRef]

48. Jepsen, D.; Vollmer, A.; Eberle, U.; Fels, J.; Schomerus, T. Entwicklung von Instrumenten zur Vermeidung von Lebensmittelabfällen [Umweltforschungsplan des Bundesministeriums für Umwelt, Naturschutz, Bau und Reaktorsicherheit]. 2014. Available online: https://www.umweltbundesamt.de/sites/default/files/ medien/378/dokumente/zusammenfassung_entwicklung_von_instrumenten_zur_vermeidung_von_ lebensmitteabfaellen_0.pdf (accessed on 7 November 2016). (In German)

49. Reducing Food Waste: How Can Retailers Help? 2014. Available online: http://www.oliverwyman. com/content/dam/oliver-wyman/global/en/2014/jul/OW_Reducing_Food_Waste.pdf (accessed on 7 November 2015). 
50. Resource Efficient Scotland (RES). Managing Food Waste in the Hospitality and Food Service Industry; Resource Efficient Scotland: Sterling, UK, 2014.

51. Self-Assessment Review for Food and Drink Manufacturers: Business Resource Efficiency Guide. 2014. Available online: http://www.wrap.org.uk/sites/files/wrap/WRAP_Food_Drink_Manufacturers.pdf (accessed on 4 January 2017).

52. Kaipia, R.; Dukovska-Popovska, I.; Loikkanen, L. Creating sustainable fresh food supply chains through waste reduction. Int. J. Phys. Distrib. Logist. Manag. 2013, 43, 262-276. [CrossRef]

53. Kreyenschmidt, J.; Albrecht, A.; Braun, C.; Herbert, U.; Mack, M.; Roissant, S.; Ritter, G.; Teitscheid, P.; Ilg, Y. Food Waste in der Fleisch verarbetenden Kette: Um Lebensmittetverluste zu minimieren, sind Handlungen entlang der Kette Fleisch notwendig. Fleischwirtschaft 2013, 93, 57-63. (In German)

54. Eriksson, M.; Strid, I.; Hansson, P. Food waste reduction in supermarkets-Net costs and benefits of reduced storage temperature. Resour. Conserv. Recycl. 2016, 107, 73-81. [CrossRef]

55. Waskow, F.; Blumenthal, A.; Eberle, U.; von Borstel, T. Situationsanalyse zu Lebensmittelverlusten im Einzelhandel, der Außer-Haus-Verpflegung Sowie in Privaten Haushalten und zum Verbraucherverhalten (SAVE); Deutsche Bundesstiftung Umwelt: Düsseldorf, Germany, 2016. (In German)

56. Pirani, S.I.; Arafat, H.A. Reduction of food waste generation in the hospitality industry. J. Clean. Prod. 2016, 132, 129-145. [CrossRef]

57. Shakman, A. Source Reduction: Automated Food Waste Tracking Systems for Food Service Operators to Minimize Waste. The Last Food Mile Conference. 2014. Available online: http://repository.upenn.edu/cgi/ viewcontent.cgi?article $=1012 \&$ context=thelastfoodmile (accessed on 8 December 2016).

58. Jedermann, R.; Nicometo, M.; Uysal, I.; Lang, W. Reducing food losses by intelligent food logistics. Philos. Trans. R. Soc. A 2014, 372, 20130302. [CrossRef] [PubMed]

59. Glatzel, C.; Hopkins, M.; Lange, T.; Weiss, U. The Secret to Smarter Fresh-Food Replenishment? Machine Learning. 2016. Available online: http://www.mckinsey.com/industries/retail/our-insights/the-secret-tosmarter-fresh-food-replenishment-machine-learning?cid=other-eml-alt-mip-mck-oth-1611 (accessed on 8 December 2016).

60. European Commission. Food and Feed Safety. 2016. Available online: http://ec.europa.eu/dgs/health_ food-safety/dyna/enews/enews.cfm?al_id=1686 (accessed on 30 December 2016).

61. BLL. Unsere Lebensmittelwirtschaft-Eine Starke Kraft für Deutschland. 2014. Available online: https://www. bll.de/embed/pb-flyer-wirtschaftskraft (accessed on 10 October 2016). (In German)

62. BVE. Jahresbericht 2015_2016: Bundesvereinigung der Deutschen Ernährungsindustrie. 2016. Available online: http://www.bve-online.de/presse/infothek/publikationen-jahresbericht/jahresbericht-2016 (accessed on 26 September 2016). (In German)

63. Richards, C.; Blackstock, K.; Carter, C. Practical Approaches to Participation. SERG Policy Brief 1. 2004. Available online: http://www.macaulay.ac.uk/ruralsustainability/SERG\%20PB1\%20final.pdf (accessed on 8 December 2016).

64. Evers, M.; Jonoski, A.; Almoradie, A.; Lange, L. Collaborative decision making in sustainable flood risk management: A socio-technical approach and tools for participatory governance. Environ. Sci. Policy 2016, 55, 335-344. [CrossRef]

65. Dutra, L.X.; Thébaud, O.; Boschetti, F.; Smith, A.D.; Dichmont, C.M. Key issues and drivers affecting coastal and marine resource decisions: Participatory management strategy evaluation to support adaptive management. Ocean Coast. Manag. 2015, 116, 382-395. [CrossRef]

66. Parry, A.; Bleazard, P.; Okawa, K. Preventing Food Waste: Case Studies of Japan and the United Kingdom. OECD Food, Agriculture and Fisheries Papers. 2015. Available online: http://www.oecd-ilibrary.org/ docserver /download /5js4w29cf0f7.pdf?expires=1446730679\&id=id\&accname=guest\&checksum=82650C15 483ED01CA3EB487F6D6643B1 (accessed on 7 November 2016).

67. Richter, B.; Bokelmann, W. Approaches of the German food industry for addressing the issue of food losses. Waste Manag. 2016, 48, 423-429. [CrossRef] [PubMed]

68. Halloran, A.; Clement, J.; Kornum, N.; Bucatariu, C.; Magid, J. Addressing food waste reduction in Denmark. Food Policy 2014, 49, 294-301. [CrossRef]

69. Derqui, B.; Fayos, T.; Fernandez, V. Towards a More Sustainable Food Supply Chain: Opening up Invisible Waste in Food Service. Sustainability 2016, 8, 693. [CrossRef] 
70. Feller, A.; Shunk, D.; Callarman, T. Value Chains versus Supply Chains. 2006. Available online: http://www. bptrends.com/publicationfiles/03-06-ART-ValueChains-SupplyChains-Feller.pdf (accessed on 9 October 2016).

71. Sroufe, R.P.; Melnyk, S.A. Developing Sustainable Supply Chains to Drive Value. Management Issues, Insights, Concepts, and Tools, 1st ed.; Business Expert Press: New York, NY, USA, 2013.

(C) 2017 by the authors; licensee MDPI, Basel, Switzerland. This article is an open access article distributed under the terms and conditions of the Creative Commons Attribution (CC-BY) license (http://creativecommons.org/licenses/by/4.0/). 